\title{
A percutan nervus tibialis stimuláció szerepe egyes kismedencei kórképek kezelésében
}

\author{
Kozma Bence dr. ${ }^{1}$ - Majoros Attila dr. ${ }^{2}$ - Pytel Ákos dr. ${ }^{3}$ \\ Póka Róbert dr. ${ }^{1}$. Takács Péter dr. ${ }^{1,4}$ \\ ${ }^{1}$ Debreceni Egyetem, Általános Orvostudományi Kar, Szülészeti és Nőgyógyászati Intézet, Debrecen \\ ${ }^{2}$ Semmelweis Egyetem, Általános Orvostudományi Kar, Urológiai Klinika, Budapest \\ ${ }^{3}$ Pécsi Tudományegyetem, Általános Orvostudományi Kar, Urológiai Klinika, Pécs \\ ${ }^{4}$ Eastern Virginia Medical School, Department of Obstetrics and Gynecology, \\ Division of Female Pelvic Medicine and Reconstructive Surgery, Norfolk, VA, Amerikai Egyesült Államok
}

\begin{abstract}
A percutan nervus tibialis stimuláció (PTNS) a legegyszerúbb, legkevésbé invazív és jól tolerálható neuromodulációs eljárás az alsó húgyutak és a székletürítés múködését befolyásoló terápiás elektrofiziológiai technikák között. A PTNS során a medencefenéki izmok és a húgyhólyag afferens idegeinek stimulációja történik a sacralis plexuson keresztül (S2-4) a nervus tibialis posterior felől egyszer használatos vékony tűelektróda és többször használatos stimulátor segítségével. A széles körű klinikai használat ellenére hatásmechanizmusa nem pontosan ismert. Hatásosnak tekinthető túlmúködő hólyag szindróma kezelése során, alkalmazása az Európai Urológiai Társaság vizeletincontinentia-irányelvének megfelelően javasolt antimuszkarinterápiára refrakter nőbetegek esetében. Túlmúködő hólyagszindrómában kezelési hatékonysága a sacralis ideg neuromudulációjához hasonló. 2003 óta alkalmazzák székletincontinentia terápiájaként, szerepe azonban a megfelelő vizsgálatok hiánya miatt egyelőre kérdéses. A hagyományos kezelési lépések hatástalansága esetén a krónikus kismedencei fájdalom terápiájában szintén szerephez jut a PTNS. Jelentős mellékhatás a PTNS használata során nem került leírásra.
\end{abstract}

Orv Hetil. 2018; 159(43): 1735-1740.

Kulcsszavak: neuromodulációs eljárás, percutan nervus tibialis stimuláció, túlmúködő hólyag szindróma, székletincontinentia, krónikus kismedencei fájdalom

\section{Efficacy of the percutaneous tibial nerve stimulation in the treatment of lower urinary tract symptoms}

Percutaneous tibial nerve stimulation (PTNS) is a minimally invasive, safe and well-tolerated neuromodulation technique for the lower urinary tract dysfunctions. PTNS delivers neuromodulation to the pelvic floor through the S2-4 junction of the sacral nerve plexus via the route of the posterior tibial nerve. Using the fine needle electrode insertion above the ankle, the tibial nerve is accessed, which connected to the stimulator. To date despite of its excessive clinical use, PTNS mechanism of action still remains unclear. The technique seems to be an efficacious and safe treatment for overactive bladder syndrome $(\mathrm{OAB})$. It could be recommended according to the Urinary Incontinence Guideline of the European Association of Urology in women who did not have adequate improvement or could not tolerate anti-muscarinic therapy. The success rate is comparable to sacral nerve stimulation in OAB patients. PTNS has been used for fecal incontinence since 2003, however, many of the published studies are of poor quality. PTNS has also been shown to have positive effects on chronic pelvic pain, when the usual therapeutic steps did not result in satisfactory improvement. No major complications are reported in the literature, following PTNS treatment.

Keywords: neuromodulation technique, percutaneous tibial nerve stimulation, overactive bladder syndrome, fecal incontinence, chronic pelvic pain

Kozma B, Majoros A, Pytel Á, Póka R, Takács P. [Efficacy of the percutaneous tibial nerve stimulation in the treatment of lower urinary tract symptoms]. Orv Hetil. 2018; 159(43): 1735-1740.

(Beérkezett: 2018. június 26.; elfogadva: 2018. július 30.) 


\section{Rövidítések}

EAU = (European Association of Urology) Európai Urológiai Társaság; ES = (electrical stimulation) elektromos stimuláció; FDA $=($ U.S. Food and Drug Administration $)$ az USA Élelmiszer-biztonsági és Gyógyszerészeti Hivatala; GRA = (Global Response Assessment) átfogó válaszértékelés; ICS = (International Continence Society) Nemzetközi Kontinencia Társaság; IF $=$ (interferential therapy) interferenciás terápia; IUGA = (International Urogynecology Association) Nemzetközi Urogynecologiai Társaság; LL-SSEP = (long-latency somatosensory evoked potential) hosszú latenciájú somatosensoros kiváltott válasz; $M S=$ (magnetic stimulation) mágneses stimuláció; $\mathrm{OAB}=$ (overactive bladder syndrome) túlmúködő hólyag szindróma; $\mathrm{OAB}-\mathrm{q}=($ Overactive Bladder Syndrome questionnaire) túlmúködő hólyag szindróma kérdőíve; PTNS = (percutaneous tibial nerve stimulation) percutan nervus tibialis stimuláció; SANS $=$ (Stoller afferent nerve stimulation $)$ Stoller-féle afferens idegstimuláció; SECCA = (radiofrequency anal sphincter remodeling) radiófrekvenciás analis sphincterr remodelláció; $\mathrm{SNM}=$ (sacral neuromodulation $)$ sacralis neuromoduláció

Az alsó húgyútak múködését és a székletürítést befolyásoló terápiás elektrofiziológiai technikák magukban foglalják mindazon elektromos stimulációs eljárásokat, amelyek az említett funkciókat szabályozó idegeket célozzák meg direkt vagy indirekt módon, így a hüvelyi és bőrfelszíni elektródákat használó medencefenéki elektromos stimulációt (ES), az interferenciás terápiát (IF), a mágneses stimulációt (MS), a sacralis neuromodulációt (SNM) és a percutan nervus tibialis stimulációt (PTNS) [1].

\section{Percutan nervus tibialis stimuláció}

A percutan nervus tibialis stimuláció a legegyszerúbb és legkevésbé invazív neuromodulációs eljárás, mely a nervus tibialis posterior elektromos szignállal történő stimulálásán keresztül eredményesen alkalmazható egyes kismedencei kórképek esetén. A módszert Stoller írta le először 1999-ben a túlmúködő hólyag szindróma (overactive bladder syndrome, OAB) kezelésére [2]. A szakirodalom ezért Stoller afferent nerve stimulation (SANS) néven is hivatkozik ezen terápiás technikára. A percutan nervus tibialis stimulációt 2000-ben engedélyezte az FDA (U.S. Food and Drug Administration) a túlmúködő hólyag szindróma kezelésében.

PTNS során a medencefenéki izmok és a húgyhólyag afferens idegeinek stimulálása a nervus tibialis posterior felől a sacralis plexuson (S2-4 segmentumból ered) keresztül történik. A kezelés során egy 34 gauge vastagságú túelektród kerül percutan beszúrásra $60^{\circ}$ szögben mintegy $5 \mathrm{~cm}$-rel cranialis irányban a malleolus medialistól és kissé posterior irányban a tibiától. A bőrfelszíni elektróda az ipsilateralis calcaneushoz kerül. Az egyszer használatos elektródák egy többször használható stimulátorhoz csatlakoznak (1. ábra). A stimulátor $20 \mathrm{~Hz}$-es frekvencián, 200 us-os négyszögimpulzusokkal, szabályozható áramerősség-intenzitással (0,5-9 mA) múködik. Az intenzitást a páciens számára még jól tolerálható legnagyobb értékre javasolt állítani. Az alapterápia 30 percig tart heti egyszeri alkalmazással, összesen 12 alkalommal ismételve [3]. Finazzi Agrò és mtsai vizsgálták, hogy heti többszöri kezeléssel fokozható-e az eredményesség. Közleményükben rámutatnak, hogy a heti három alkalommal végzett stimuláció nem hatékonyabb a heti rendszerességgel végzettel szemben, ugyanakkor a gyakoribb kezelés hatására a kívánt eredményesség 12 helyett 4 hét alatt is elérhető [4]. Eredményeik alapján úgy tűnik, hogy a kedvező hatás kiváltása inkább a kezelések számától, mint az első kezelés óta eltelt időtől függ. Yoong és mtsai rövidített, 6 hetes protokoll eredményeit közölték: a túlműködő hólyag szindróma miatt kezelt 43 nőbeteg 69,7\%-ában volt észlelhető javulás [5]. Számos tanulmány megerősíti, hogy a PTNS jól tolerálható [6]. Ridout és mtsa $\mathrm{OAB}$ miatt kezelt betegeknél átmeneti mellékhatásként a tûszúrás miatt lokális diszkomfortérzést $(1,8 \%)$ és vérzést $(2,7 \%)$, illetve lábzsibbadást $(0,9 \%)$ írt le [7]. Tartósan fennálló mellékhatásról mindösszesen egy közlemény számol be, ahol 8000 kezelésből két esetben elhúzódó neuropátiát írtak le [8].

A széles körü klinikai használat ellenére a PTNS pontos hatásmechanizmusa mindmáig nem minden részletében ismert. Állatkísérletes modellekben a hátsó lábak, illetve a nervus pudendalis elektromos ingerlése detrusorgátlást eredményezett $[9,10]$. Tai és mtsai macskával végzett kísérletükben a nervus tibialis elektromos ingerlésével eredményesen gátolták az irritációval kiváltott hólyagtúlmúködést $[9,11]$. Danisman és mtsai a hízósejtek számbeli csökkenését figyelték meg PTNS-kezelés után patkányhúgyhólyagban [12]. Szintén patkányokon került igazolásra a PTNS sacralis gerincvelőre gyakorolt hatása. Chang és mtsai a c-fos-expresszió (idegi metabo-

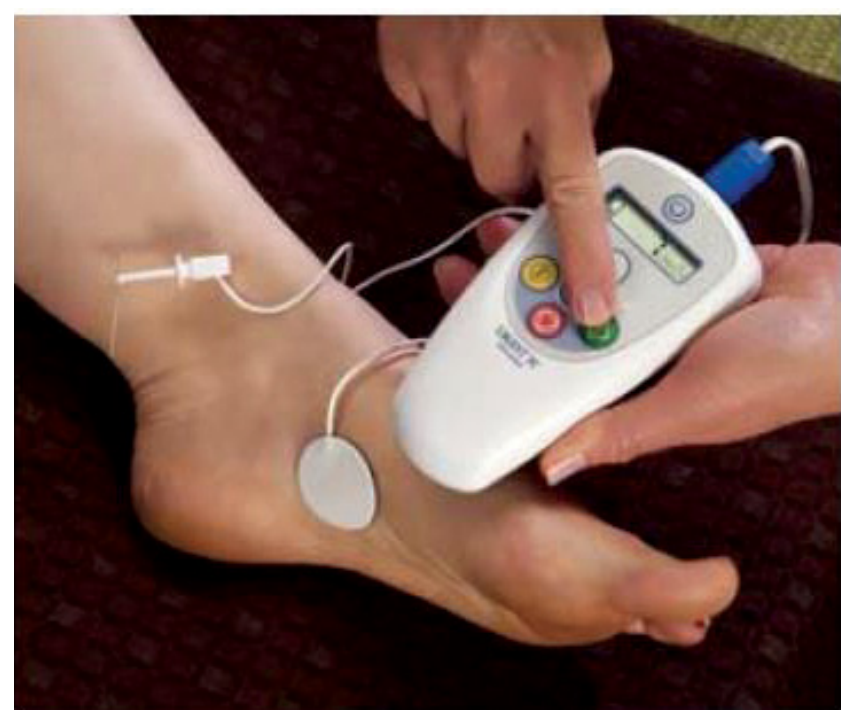

1. ábra

Percutan nervus tibialis stimuláció (Urgent PC Stimulator; Cogentix Medical, Orangeburg, NY, Amerikai Egyesült Államok) 
likus aktivitást jelző marker) csökkenését mérték patkánygerincvelőben a hátsó lábak elektromos stimulálása után [13]. A PTNS supraspinalis hatását humán kísérletben is sikerült igazolni. Finazzi Agrò és mtsai az LLSSEP (long-latency somatosensory evoked potential) amplitúdójának szignifikáns növekedését írták le a 12 alkalommal végzett stimuláció utolsó kezelése után 24 órával [14], ami felveti, hogy a PTNS tartósan megváltoztathatja a kortikális ingerelhetőséget, illetve a vizelési inger agyi tudatosulását.

\section{Túlmüködő hólyag szindróma (overactive bladder syndrome - OAB)}

A Nemzetközi Urogynecologiai Társaság (IUGA) és a Nemzetközi Kontinencia Társaság (ICS) meghatározása szerint a túlmúködő hólyag szindróma jellemzője a parancsoló vizelési inger, késztetéses incontinentiával vagy a nélkül, rendszerint gyakori nappali és éjszakai vizeletürítéssel társulva, gyulladásos kórkép vagy más nyilvánvaló ok nélkül [15]. Prevalenciája férfiakban 5,9\% és 16\%, míg nőkben 6\% és 16,9\% között változik, és az életkorral együtt nő [16]. A túlmúködő hólyag szindróma jelentősen befolyásolja az életminőséget, az alvást, a szexuális életet, a mentális egészséget, a munkavégzést és az egészségügyi kiadásokat [17-19]. Az OAB első vonalbeli kezelési lehetôségei az életmód-változtatás, a viselkedésterápia (hólyagtréning vagy toalett-tréning), a medencefenéki izomtorna (gátizomtorna), illetve a vizelet tárolását segítő gyógyszeres kezelések (antimuszkarinek, béta-3-adrenoreceptor-agonisták). Sajnos a betegek körében a viselkedésterápiás és egyéb gyógytornakezelések népszerüsége elmarad a kívánttól. Az antimuszkaringyógyszerek esetében pedig a kellemetlen mellékhatások (szájszárazság, székrekedés stb.) miatt nagy a terápiás lemorzsolódás aránya. Felmérések szerint az oxibutinint szedő betegek fele elhagyja a gyógyszert az első két hónap után, és mindösszesen a betegek 22\%-a folytatja a kezelést fél évet követően is. Az új támadáspontú és így lényegesen kevesebb mellékhatást okozó béta-3-adrenoreceptor-agonista mirabegron hazákban sajnos még nem érhető el támogatott formában. Éppen ezért kiemelt fontosságú a korai kontrollvizsgálat gyógyszeres terápia esetén $[20,21]$. Amennyiben az első vonalbeli kezelések 6 hónap után sem hoznak eredményt, a leggyakrabban detrusorba injektált botolinumtoxin-injekció, sacralis neuromoduláció, illetve kifejezetten beszúkült hólyagcompliance esetén végső megoldásként hólyagaugmentáció jöhet szóba [22]. Az előbbiekben említett másod-, illetve harmadvonalbeli mütéti kezelésekkel szemben a PTNS egy minimálisan invazív ambuláns kezelési módszer. A két neuromodulációs technika között lényeges különbség, hogy míg az SNM esetén az elektródákat az impulzusgenerátorral együtt implantálni kell (ez képezi egyben az idegstimuláció közvetlen lehetőségét is), addig a PTNS - mint minimálisan invazív kezelési módszer - esetén a sacralis ideggyök közvetett ingerlése történik egyszer használatos, tartósan nem implantálandó elektródákon keresztül. Emellett megjegyzendő, hogy a PTNS-kezelés költsége az SNM-hez képest jelentősen alacsonyabb [23]. A European Association of Urology (EAU) vizeletincontinentia-irányelve javasolja a PTNS végzését $\mathrm{OAB} /$ urge incontinens panasszal bíró, antimuszkarinterápiára refrakter női betegeknél (LE:2b, GrR:B) [21, 24].

A PTNS-kezelés színlelt kezeléssel (sham treatment) szembeni hatékonyságát l-es szintü bizonyítékokkal igazolták. A vizelési gyakoriság és a késztetéses vizeletincontinens epizódok számának csökkenése a különböző közleményekben eltérő mértékü [25]. Egyes szerzők ugyanakkor kiemelik, hogy a vizelési epizódok számának nem szignifikáns mértékű csökkenése is jelenthet jelentős életminőség-javulást a kezelt pácienseknél. Peters és mtsai cikkükben rámutatnak, hogy a kezelt csoportban az incontinens epizódok kismértékú csökkenése mellett szignifikáns javulást mértek a Global Response Assessment (GRA) és a túlmúködő hólyag szindróma kérdőívein (OAB-q) [3]. Ugyanebben a közleményben a 'sham' csoporton belül is szignifikáns javulás volt észlelhető a kiindulási állapothoz képest, ami felveti, hogy a PTNS-kezelésnek placeboszerü hatása is lehet. Peters és mtsai más közleményükben összehasonlították a hosszú hatású tolterodinterápiát és a PTNS-kezelést [26]. Bár az objektív mérôszámokban hasonló javulás mutatkozott a két kezelési csoport között, a PTNS-kezelésben részt vevő betegek a GRA- és az OAB-q-kérdőíveken keresztül szignifikánsan nagyobb arányban jelezték a szubjektív tünetek javulását. A közlemény szerint ennek hátterében a leginkább a PTNS-karon lévő betegek kisebb mellékhatásrátája és a késztetéses tünetek nagyobb mértékú csökkenése állhat. A PTNS-kezelés antikolinerg gyógyszerekkel kombinálva további javulást eredményezhet [27]. Az OAB, illetve az urodinamikailag igazolt detrusortúlmúködés miatt PTNS-kezelésben részesült betegeknél egyes közlemények beszámolnak az urodinamikai paraméterek változásáról is. Klingler és mtsai a detrusortúlmúködés csökkenését, Vandoninck és mtsai a cisztometriai kapacitás és az első detrusorkontrakciónál mért hólyagtérfogat növekedését írták le [28, 29]. A vonatkozó irodalom áttekintése során megállapítottuk, hogy inkább a női populációban vizsgálták a PTNS OAB-re gyakorolt hatását, ugyanakkor olyan vizsgálati eredmények is elérhetők, amelyekben a nemek aránya megegyezik [30]. Tutolo és mtsai összefoglaló közleménye alapján az SNM sikerességi rátája 61-90\%, míg PTNS esetében ez 54-79\%. SNM esetén a mütétes revíziót igénylő komplikációk aránya 9-33\%, míg PTNS esetében jelentős komplikáció nem került leírásra [31].

\section{Székletincontinentia}

A székletincontinentia prevalenciája a fejlett országok felnőttpopulációiban $2 \%$ és $20 \%$ között van, és a leginkább a 65 év fölötti nőket érinti [32-35]. Azon betegek- 
nél, akiknél konzervatív kezeléssel nem érhető el megfelelő javulás, invazív kezelési lehetőségek is szükségessé válhatnak, úgymint a sphincter-helyreállító mútétek, párnaképző anyagok injektálása [36], radiofrekvenciás ablatio (SECCA) [37], illetve műsphincter-implantáció [38]. Azon betegek kivételével, akiknél az etiológia alapját a záróizomgyưrű disruptiója képezi, a fenti invazív terápiás lehetőségek alacsony hatékonysággal alkalmazhatók, bár az újabb párnaképző anyagok használata ígéretes [39]. A PTNS alkalmazását székletincontinentiában először Shafik írta le 2003-ban [40]. Hasonlóan az OAB-hez, a székletincontinentia terápiájában sem ismert a PTNS, illetve az SNM pontos hatásmechanizmusa. Leginkább különböző fiziológiai hatások együttes szerepéről van szó, úgymint a lokális somatovisceralis reflex megváltozása, ami a colon motilitásának és az analis sphincter aktivitásának megváltozásához vezet, valamint közrejátszhat az afferens információk magasabb szintú percepciójának módosulása is [41-44]. Ugyanakkor sem a PTNS-, sem az SNM-kezelések alatt nem került leírásra ez idáig olyan anorectalis fiziológiai változás, amely következetesen észlelhető lenne [45]. Más szerzőkkel összhangban Govaert és mtsai a vizsgálatukba bevont, PTNSkezelésben részesített páciensek 60\%-ánál észleltek legalább 50\%-os csökkenést a székletincontinens epizódok számában [46]. Mentes és mtsai kis betegszámot feldolgozó tanulmányukban a PTNS használatát részleges gerincvelő-sérülés esetén is ígéretesnek tartották [47]. Horrocks és mtsai összefoglaló közleményükben megállapították, hogy bár a székletincontinentia esetében a PTNS szignifikáns javuláshoz vezet számos vizsgált paraméter esetén, megfelelő esetszámú, adekvát, randomizált-kontrollált tanulmány hiányában a PTNS szerepe a székletincontinentia kezelésében egyelőre kérdéses [48].

\section{Krónikus kismedencei fájdalom}

A krónikus kismedencei fájdalom szindróma definíció szerint olyan intermittáló vagy állandó alhasi vagy kismedencei fájdalom, amely nem terhes állapotban legalább hat hónapja tart, és nem köthető a menstruációhoz vagy a szexuális együttlétekhez, illetve a húgyúti fertőzés kizárható [49]. Élettartam-prevalenciája a nők körében $33 \%$, míg a reproduktív életszakaszt tekintve 12\% [50]. A krónikus kismedencei fájdalom életminőségre gyakorolt negatív hatása összemérhető olyan krónikus betegségekkel, mint a diabetes mellitus, a Crohn-betegség vagy a szívelégtelenség [51]. A betegek egy jelentős részénél a számos terápiás lehetőség ellenére sem érhető el a kívánt javulás. Bár a PTNS fájdalomra gyakorolt kedvező hatásával számos közlemény foglalkozik, igen kevés azon tanulmányok száma, amelyek a fájdalmat mint elsődlegesen vizsgált tényezőt kutatják a PTNS használata során. Van Balken és mtsai vizsgálták először a PTNS-kezelés hatását a krónikus kismedencei fájdalomra [52]. Prospektív multicentrikus tanulmányukban 33 beteg adatait feldolgozva a páciensek $42 \%$-a mutatott javulást a vizu- ális analóg skála és a McGill-fájdalomkérdooív alapján. Gokyildiz és mtsai prospektív randomizált vizsgálatukban a kezelt csoportban szignifikáns csökkenést tapasztaltak a fájdalom gyakorisága és intenzitása, valamint kismértékű javulást a szexuális funkció tekintetében [53]. Istek és mtsai a leírt kedvező hatások tartósságának vizsgálatakor megállapították, hogy a fájdalom csökkenése a kezdeti értékhez képest a 12 hetes kezelés végén, illetve a kezelés befejezését követő harmadik hónapban nem mutatott különbséget [54]. A neuromoduláció fájdalomra kifejtett hatásmechanizmusa nem ismert pontosan, de szerepe lehet a somaticus idegi stimuláción keresztüli A-deltavagy C-rostok gátlásának, az endorfinszint emelkedésének az adott gerincvelői szinten és a c-fos-expresszió csökkenésének a központi idegrendszerben $[13,55]$.

\section{Következtetés}

A percutan nervus tibialis stimuláció egy széles körben alkalmazható, minimálisan invazív, biztonságos, egyszerü, könnyen elsajátítható, hatékony és ambuláns körülmények között végezhető, szükség esetén ismételhető neuromodulációs technika. Az intenzív kutatások ellenére hatásmechanizmusa nem pontosan ismert. Eredményesen használható túlmúködő hólyag szindrómával kezelt betegeknél eredménytelen első vonalbeli kezelést követően, a székletincontinentia olyan eseteiben, ahol egyértelmú anatómiai ok nem azonosítható, illetve a krónikus kismedencei fájdalom szindrómában, amennyiben a hagyományos terápiás lépések nem vezetnek eredményre.

Anyagi támogatás: A közlemény megírása, illetve a kapcsolódó kutatómunka anyagi támogatásban nem részesült.

Szerzői munkamegosztás: K. B.: Adatgyújtés, a közlemény megírása. M. A., P. Á., P. R.: A közlemény javítása, kiegészítése. T. P.: Adatgyüjtés, a közlemény javítása, kiegészítése, végleges korrektúra. A cikk végleges változatát valamennyi szerző elolvasta és jóváhagyta.

Érdekeltségek: A szerzőknek nincsenek érdekeltségeik.

\section{Irodalom}

[1] Yamanishi T, Kamai T, Yoshida K. Neuromodulation for the treatment of urinary incontinence. Int J Urol. 2008; 15: 665672.

[2] Stoller ML. Afferent nerve stimulation for pelvic floor dysfunction. Eur Urol. 1999; 35(Suppl. 2): 16.

[3] Peters KM, Carrico DJ, Perez-Marrero RA, et al. Randomized trial of percutaneous tibial nerve stimulation versus Sham efficacy in the treatment of overactive bladder syndrome: results from the SUmiT trial. J Urol. 2010; 183: 1438-1443.

[4] Finazzi Agrò E, Campagna A, Sciobica F, et al. Posterior tibial nerve stimulation: is the once-a-week protocol the best option? Minerva Urol Nefrol. 2005; 57: 119-123. 
[5] Yoong W, Ridout AE, Damodaram M, et al. Neuromodulative treatment with percutaneous tibial nerve stimulation for intractable detrusor instability: outcomes following a shortened 6-week protocol. BJU Int. 2010; 106: 1673-1676.

[6] Cooperberg MR, Stoller ML. Percutaneous neuromodulation. Urol Clin North Am. 2005; 32: 71-78, vii.

[7] Ridout AE, Yoong W. Tibial nerve stimulation for overactive bladder syndrome unresponsive to medical therapy. J Obstet Gynaecol. 2010; 30: 111-114.

[8] Zhou D, Seraphim A, Yoong W. Tibial sensory neuropathy as a rare complication of percutaneous tibial nerve stimulation. Int Urogynecol J. 2015; 26: 301-302.

[9] Tai C, Chen M, Shen B, et al. Irritation induced bladder overactivity is suppressed by tibial nerve stimulation in cats. J Urol. 2011; 186: 326-330.

[10] Jiang CH, Lindstrom S. Prolonged enhancement of the micturition reflex in the cat by repetitive stimulation of bladder afferents. J Physiol. 1999; 517(Pt 2): 599-605.

[11] Tai C, Shen B, Chen M, et al. Prolonged poststimulation inhibition of bladder activity induced by tibial nerve stimulation in cats. Am J Physiol Renal Physiol. 2011; 300: F385-F392.

[12] Danisman A, Kutlu O, Akkaya E, et al. Tibial nerve stimulation diminishes mast cell infiltration in the bladder wall induced by interstitial cystitis urine. Scand J Urol Nephrol. 2007; 41: 98102

[13] Chang CJ, Huang ST, Hsu K, et al. Electroacupuncture decreases c-fos expression in the spinal cord induced by noxious stimulation of the rat bladder. J Urol. 1998; 160: 2274-2279.

[14] Finazzi Agrò E, Rocchi C, Pachatz C, et al. Percutaneous tibial nerve stimulation produces effects on brain activity: study on the modifications of the long latency somatosensory evoked potentials. Neurourol Urodyn. 2009; 28: 320-324.

[15] Haylen BT, de Ridder D, Freeman RM, et al. An International Urogynecological Association (IUGA)/International Continence Society (ICS) joint report on the terminology for female pelvic floor dysfunction. Neurourol Urodyn. 2010; 29: 4-20.

[16] Wang Y, Xu K, Hu H, et al. Prevalence, risk factors, and impact on health related quality of life of overactive bladder in China. Neurourol Urodyn. 2011; 30: 1448-1455.

[17] Irwin DE, Milsom I, Hunskaar S, et al. Population-based survey of urinary incontinence, overactive bladder, and other lower urinary tract symptoms in five countries: results of the EPIC study. Eur Urol. 2006; 50: 1306-1314; discussion 1314-1315.

[18] Stewart WF, Van Rooyen JB, Cundiff GW, et al. Prevalence and burden of overactive bladder in the United States. World J Urol. 2003; 20: 327-336

[19] Ganz ML, Smalarz AM, Krupski TL, et al. Economic costs of overactive bladder in the United States. Urology 2010; 75 : 526532 .

[20] Chapple C, Khullar V, Gabriel Z, et al. The effects of antimuscarinic treatments in overactive bladder: a systematic review and meta-analysis. Eur Urol. 2005; 48: 5-26.

[21] Majoros A, Bajory Z, Pytel A, et al. Ministry of Human Capacities. Guideline on non-neurogenic adult urinary incontinence. [Az Emberi Erőforrások Minisztériuma szakmai irányelve a felnőttkorban előforduló, nem neurogén eredetű vizeletinkontinenciáról.] Egészségügyi Közl. 2016; LXV: 1180-1200. [Hungarian]

[22] Abrams P, Andersson KE, Birder L, et al. Fourth International Consultation on Incontinence Recommendations of the International Scientific Committee: Evaluation and treatment of urinary incontinence, pelvic organ prolapse, and fecal incontinence. Neurourol Urodyn. 2010; 29: 213-240.

[23] Kurdoğlu Z, Carr D, Harmouche J, et al. Short-term results of the efficacy of percutaneous tibial nerve stimulation on urinary symptoms and its financial cost. J Turk Ger Gynecol Assoc. 2018; 19: 7-10
[24] Nambiar AK, Bosch R, Cruz F, et al. EAU guidelines on assessment and nonsurgical management of urinary incontinence. Eur Urol. 2018; 73: 596-609.

[25] Moossdorff-Steinhauser HF, Berghmans B. Effects of percutaneous tibial nerve stimulation on adult patients with overactive bladder syndrome: a systematic review. Neurourol Urodyn. 2013; 32: 206-214.

[26] Peters KM, Macdiarmid SA, Wooldridge LS, et al. Randomized trial of percutaneous tibial nerve stimulation versus extendedrelease tolterodine: results from the overactive bladder innovative therapy trial. J Urol. 2009; 182: 1055-1061.

[27] Vecchioli-Scaldazza C, Morosetti C. Effectiveness and durability of solifenacin versus percutaneous tibial nerve stimulation versus their combination for the treatment of women with overactive bladder syndrome: a randomized controlled study with a followup of ten months. Int Braz J Urol. 2018; 44: 102-108.

[28] Klingler HC, Pycha A, Schmidbauer J, et al. Use of peripheral neuromodulation of the S3 region for treatment of detrusor overactivity: a urodynamic-based study. Urology 2000; 56: $766-$ 771.

[29] Vandoninck V, van Balken MR, Finazzi Agrò E, et al. Percutaneous tibial nerve stimulation in the treatment of overactive bladder: urodynamic data. Neurourol Urodyn. 2003; 22: 227-232.

[30] van der Pal F, van Balken MR, Heesakkers JP, et al. Percutaneous tibial nerve stimulation in the treatment of refractory overactive bladder syndrome: is maintenance treatment necessary? BJU Int. 2006; 97: 547-550.

[31] Tutolo M, Ammirati E, Heesakkers J, et al. Efficacy and safety of sacral and percutaneous tibial neuromodulation in non-neurogenic lower urinary tract dysfunction and chronic pelvic pain: a systematic review of the literature. Eur Urol. 2018; 73: 406418.

[32] Perry S, Shaw C, McGrother C, et al. Prevalence of faecal incontinence in adults aged 40 years or more living in the community. Gut 2002; 50: 480-484.

[33] Nelson R, Norton N, Cautley E, et al. Community-based prevalence of anal incontinence. JAMA 1995; 274: 559-561.

[34] Ho YH, Muller R, Veitch C, et al. Faecal incontinence: an unrec ognised epidemic in rural North Queensland? Results of a hospital-based outpatient study. Aust J Rural Health 2005; 13: 28-34.

[35] Goode PS, Burgio KL, Halli AD, et al. Prevalence and correlates of fecal incontinence in community-dwelling older adults. J Am Geriatr Soc. 2005; 53: 629-635.

[36] Maeda Y, Laurberg S, Norton C. Perianal injectable bulking agents as treatment for faecal incontinence in adults. Cochrane Database Syst Rev. 2013; 2: CD007959.

[37] Kim DW, Yoon HM, Park JS, et al. Radiofrequency energy delivery to the anal canal: is it a promising new approach to the treatment of fecal incontinence? Am J Surg. 2009; 197: 14-18.

[38] Ruiz Carmona MD, Alos Company R, Roig Vila JV, et al. Longterm results of artificial bowel sphincter for the treatment of severe faecal incontinence. Are they what we hoped for? Colorectal Dis. 2009; 11: 831-837.

[39] Ratto C, Parello A, Donisi L, et al. Novel bulking agent for faecal incontinence. Br J Surg. 2011; 98: 1644-1652.

[40] Shafik A, Ahmed I, El-Sibai O, et al. Percutaneous peripheral neuromodulation in the treatment of fecal incontinence. Eur Surg Res. 2003; 35: 103-107.

[41] Matzel KE. Sacral nerve stimulation for faecal incontinence: its role in the treatment algorithm. Colorectal Dis. 2011; 13(Suppl 2): 10-14.

[42] Gourcerol G, Vitton V, Leroi AM, et al. How sacral nerve stimulation works in patients with faecal incontinence. Colorectal Dis. 2011; 13: e203-e211.

[43] Giani I, Novelli E, Martina S, et al. The effect of sacral nerve modulation on cerebral evoked potential latency in fecal incontinence and constipation. Ann Surg. 2011; 254: 90-96. 
[44] Griffin KM, Pickering M, O'Herlihy C, et al. Sacral nerve stimulation increases activation of the primary somatosensory cortex by anal canal stimulation in an experimental model. Br J Surg. 2011; 98: 1160-1169.

[45] Carrington EV, Knowles CH. The influence of sacral nerve stimulation on anorectal dysfunction. Colorectal Dis. 2011; 1(Suppl 2): $5-9$.

[46] Govaert B, Pares D, Delgado-Aros S, et al. A prospective multicentre study to investigate percutaneous tibial nerve stimulation for the treatment of faecal incontinence. Colorectal Dis. 2010; 12: 1236-1241

[47] Mentes BB, Yüksel O, Aydin A, et al. Posterior tibial nerve stimulation for faecal incontinence after partial spinal injury: preliminary report. Tech Coloproctol. 2007; 11: 115-119.

[48] Horrocks EJ, Thin N, Thaha MA, et al. Systematic review of tibial nerve stimulation to treat faecal incontinence. $\mathrm{Br}$ J Surg. 2014; 101: 457-468.

[49] ACOG Practice Bulletin No. 51. Chronic pelvic pain. Obstet Gynecol. 2004; 103: 589-605.

[50] Jamieson DJ, Steege JF. The prevalence of dysmenorrhea, dyspareunia, pelvic pain, and irritable bowel syndrome in primary care practices. Obstet Gynecol. 1996; 87: 55-58.
[51] Walter M, Sammer U, Kessler TM. Chronic pelvic pain syndrome: neurostimulation, neuromodulation and acupuncture. Urologe A 2012; 51: 1683-1691.

[52] van Balken MR, Vandoninck V, Messelink BJ, et al. Percutaneous tibial nerve stimulation as neuromodulative treatment of chronic pelvic pain. Eur Urol. 2003; 43: 158-163; discussion 163.

[53] Gokyildiz S, Kizilkaya Beji N, Yalcin O, et al. Effects of percutaneous tibial nerve stimulation therapy on chronic pelvic pain. Gynecol Obstet Invest. 2012; 73: 99-105.

[54] Istek A, Gungor Ugurlucan F, Yasa C, et al. Randomized trial of long-term effects of percutaneous tibial nerve stimulation on chronic pelvic pain. Arch Gynecol Obstet. 2014; 290: 291-298.

[55] Bemelmans BL, Mundy AR, Craggs MD. Neuromodulation by implant for treating lower urinary tract symptoms and dysfunction. Eur Urol. 1999; 36: 81-91.

(Kozma Bence dr.,

Debrecen, Nagyerdei krt. 98., 4032 e-mail: bence.kozma@med.unideb.hu)

\section{PÁLYÁZAT}

A Prof. Dr. Romics László Akadémikus Emlékére Alapítvány pályázatot hirdet Magyarországon dolgozó, magyar állampolgárságú, 40 éven aluli orvosok és orvosbiológiai kutatással foglalkozó személyek számára. A nyertes pályázó(k) között 500000 Ft alapítványi adomány kerül kiosztásra.

A pályázat célja: a klinikai gyógyítás vagy orvosi tudományos kutatás területén dolgozók kiemelkedő tudományos tevékenységének elismerése.

Előnyt élveznek azok a pályázók, akik az alapítvány névadójának munkásságát folytatva cardiovascularis és anyagcsere-betegségek területéről nyújtanak be pályázatot.

A pályázat benyújtásának határideje: 2019. január 31. (elbírálásának határideje: 2019. április 30.)

A pályázatot a palyazat@romicsalapitvany.hu e-mail címre pdf formátumban kell benyújtani.

A pályázatot természetes személy, saját nevében, magyar nyelven nyújthatja be, a pályázati anyag ábrák nélkül maximum 15000 leütés (karakter) terjedelmü lehet. A pályázathoz mellékelni kell egy rövid szakmai életrajzot a születési év megjelölésével.

A pályázat benyújtását saját kézzel aláírt és dátummal ellátott levélben kell bejelenteni az alapítvány titkárának címezve (a borítékra írandó cím: dr. Dudás Márta, 1461 Budapest, Pf 62.) könyvelt (ajánlott) küldeményben, mert ezen bejelentés alapján válik hitelessé a pályázat. A pályázatot nyomtatott formában nem kell mellékelni.

Az alapítvány adatairól, müködéséről a www.romicsalapitvany.hu honlapon található információ.

A cikk a Creative Commons Attribution-NonCommercial 4.0 International License (https://creativecommons.org/licenses/by-nc/4.0) feltételei szerint publikált Open Access közlemény, melynek szellemében a cikk nem kereskedelmi célból bármilyen médiumban szabadon felhasználható, megosztható és újraközölhető, feltéve, hogy az eredeti szerző és a közlés helye, illetve a CC License linkje és az esetlegesen végrehajtott módosítások feltüntetésre kerülnek. 